\title{
Phytochemical Constituents and Biological Activities of Melicope lunu-ankenda
}

\author{
Enas Mohamed Eliaser ${ }^{1}$, Jun Hui Ho ${ }^{2}$, Najihah Mohd. Hashim ${ }^{3,4}$, Yaya Rukayadi ${ }^{5}$, \\ Gwendoline Cheng Lian Ee ${ }^{6}$ and Ahmad Faizal Abdull Razis $5,7,8, *$ (D) \\ 1 UPM-MAKNA Cancer Research Laboratory, Institute of Bioscience, Universiti Putra Malaysia, \\ 43400 UPM Serdang, Selangor, Malaysia; en_mo2008@yahoo.com \\ 2 Unit of Genetics and Molecular Biology, Institute of Biological Sciences, Faculty of Science, \\ University of Malaya, Jalan Universiti, 50603 Kuala Lumpur, Malaysia; winxonho@gmail.com \\ 3 Pharmacy Department, Faculty of Medicine, University of Malaya, 50603 Kuala Lumpur, Malaysia; \\ najihahmh@um.edu.my \\ 4 Center of Natural Product Research and Drug Discovery (CENAR), University of Malaya, \\ 50603 Kuala Lumpur, Malaysia \\ 5 Department of Food Science, Faculty of Food Science and Technology, Universiti Putra Malaysia, \\ 43400 UPM Serdang, Selangor, Malaysia; yaya_rukayadi@upm.edu.my \\ 6 Chemistry Department, Faculty of Science, Universiti Putra Malaysia, 43400 UPM Serdang, Selangor, \\ Malaysia; gwendolinechenglian@gmail.com \\ 7 Laboratory of Molecular Biomedicine, Institute of Bioscience, Universiti Putra Malaysia, \\ 43400 UPM Serdang, Selangor, Malaysia \\ 8 Laboratory of Food Safety and Food Integrity, Institute of Tropical Agriculture and Food Security, \\ Universiti Putra Malaysia, 43400 UPM Serdang, Selangor, Malaysia \\ * Correspondence: madfaizal@upm.edu.my; Tel.: +603-89472115
}

Received: 20 September 2018; Accepted: 18 October 2018; Published: 20 October 2018

\begin{abstract}
Natural products, either pure compounds or standardized plant extracts, have provided opportunities for the discovery of new drugs. Nowadays, most of the world's population still relies on traditional medicines for healthcare purposes. Plants, in particular, are always used as traditional medicine, as they contain a diverse number of phytochemicals that can be used for the treatment of diseases. The multicomponent feature in the plants is considered a positive phytotherapeutic hallmark. Hence, ethnopharmacognosy has been the focus for finding alternative treatments for diseases. Melicope lunu-ankenda, also known as Euodia lunu-ankenda, is widely distributed in tropical regions of Asia. Different parts of M. lunu-ankenda have been used for treatment of hypertension, menstrual disorder, diabetes, and fever, and as an emmenagogue and tonic. It has also been consumed as salad and as a condiment for food flavorings. The justification of use of M. lunu-ankenda in folk medicines is supported by its reported biological activities, including its cytotoxic, antibacterial, antioxidant, analgesic, antidiabetic, and anti-inflammatory activities. This review summarizes the phytochemical compounds isolated from various parts of $M$. lunu-ankenda, such as root and leaves, and also its biological activities, which could make the species a new therapeutic agent for some diseases, including diabetes, in the future.
\end{abstract}

Keywords: Melicope lunu-ankenda; Rutaceae; phytochemical; biological activities; ethnopharmacognosy

\section{Introduction}

In the last few decades, herbal drugs have gained increased popularity in the treatment of ailments. The unparalleled availability of chemical diversity of herbal products allows them to provide limitless opportunities for the discovery of new drugs. In Asia, the use of traditional medicines derived from 
herbs represents a long history of interactions between humans and their environments. Plants that have been used for the production of traditional medicines are found to contain many different phytochemical compounds that can be used for the treatment of chronic and infectious diseases [1]. Due to increasing microbial resistance and the undesirable side effects of chemically synthesized drugs, the use of herbs to make natural drugs has become topical again [1,2]. Many phytochemical compounds have been found to be safe and effective with lower adverse effects than chemically synthesized drugs, and their beneficial biological activities such as anticancer, antimicrobial, antioxidant, antidiarrheal, analgesic, and wound-healing activities have been reported [1]. Under many circumstances, people have claimed the benefits of certain natural or herbal products. Nonetheless, clinical trials need to be conducted to demonstrate the effectiveness of bioactive compounds to verify the claim. Besides, a careful evaluation is required for the trials that are directed to understand the pharmacokinetics, bioavailability, efficacy, safety, and drug interactions of new bioactive compounds and their formulations [1]. This review focuses on Melicope lunu-ankenda, which is well-known for its medicinal application in folk medicine tradition. A lot of studies have reported on the phytochemical compounds that have been isolated from different parts of the plant such as its root, leaves, and stem, and biological activities, which both will be described in this review.

\subsection{The Family Rutaceae}

M. lunu-ankenda is a species belonging to the family Rutaceae. The leaves are pinnate, trifoliolate, or unifoliolate but less commonly simple; and alternate or spirally arranged, opposite, whorled (rare), and are frequently dotted with oil glands, which appear as dark green spots beneath surface while as translucent spots when they are exposed to light [3,4]. The inflorescences are either terminal or axillary panicles, cymes, racemes, or solitary (uncommon) and epiphyllous (rare). The flowers are bisexual or unisexual, and regular or irregular (rare). Seeds are usually ovoid to ellipsoid shape or oblong, and with or without endosperm [3]. In addition, spines and thorns are occasionally found on their twigs and branches, and an aromatic or lime-like scent from broken twigs, fruits, or crushed leaves enables them to be easily recognized [4].

This family consists of about 160 genera and 1650 species. The species are widely distributed and are found primarily in tropical and subtropical regions. In Malaysia, particularly in Sabah and Sarawak, 23 genera and 75 species are found, of which 17 genera and 43 species are native trees and shrubs [3]. Those native species exist in various habitats, ranging from hills and mountains, lowlands, coastal areas, and offshore islands. Most of the species are found below $1300 \mathrm{~m}$ elevation, but a few of them can grow to higher altitudes such as Citrus and Tetractomia to $1800 \mathrm{~m}$, and Melicope to $2400 \mathrm{~m}$. The species perpetuate by dispersing fruits and seeds through birds (Melicope, Zanthoxylum), wind (Tetractomia), water (Merope), and fruit and seed-eating animals (Citrus, Clausena, Glycosmis, Micromelum, Severinia, and most other Aurantioideae). The species in this family are used for various different purposes, such as food sources, flavorings, traditional medicines, edible fruits, timber for construction, and ornamentals [3].

\subsection{The Genus Melicope}

In the genus Melicope, the leaves are opposite or whorled, and trifoliolate, unifoliolate, or simple. The inflorescences are axillary, lateral, or terminal (rare). The flowers are bisexual or unisexual and 4-merous. The number of stamens can be the same or twice the number of petals, and carpels are 2-ovulate. The seeds are shiny, smooth, and remain attached in dehisced fruits [5].

Melicope species are distributed in tropical regions, including Mascarene Island, the Hawaiian Islands, Australia, New Zealand, East and South Asia, and Polynesia [3,4]. It contains about 230 species, of which about 14 of them are found in Sabah and Sarawak, while another 10 species are distributed on the Malayan Peninsula [3,6].

Melicope has similar characteristics with other two closely related genera in the same family, Tetradium Lour. and Euodia J. R. Forst. and G. Forst. Previously, Tetradium was treated as a section 
of Euodia by a German botanist, Heinrich Gustav Adolf Engler, in his standard major work on the southeast Asian Pacific Rutaceae. Then, Thomas Gordon Hartley [5] transferred many species from Euodia to Melicope J. R. and G. Forst. The main morphological differences between Euodia, Tetradium, and Melicope are given in Table 1.

Table 1. Main morphological differences between genera Euodia, Tetradium, and Melicope. Adapted from Hartley [5].

\begin{tabular}{cll}
\hline Genus & & \multicolumn{1}{c}{ Main Morphological Difference } \\
\hline \multirow{2}{*}{ Euodia } & - & Seeds dull and roughened, discharge when follicle dehisces \\
& - & Leaves trifoliolate or unifoliolate \\
Tetradium & - & Snflorescences axillary \\
& - & Leaves pinnately compound \\
& - & Inflorescences terminal or terminal and from the axils of the uppermost leaves pair \\
\hline & - & Seeds shiny and smooth, remain attached in the dehisced fruit \\
& - & Leaves trifoliolate, unifoliolate or simple \\
& &
\end{tabular}

M. lunu-ankenda, which is also known as Evodia lunu-ankenda (Gaertn.) Merr., is one of the species in the genus Melicope. It is most closely related to M. glabra and is mainly distributed in tropical regions of Asia, from Himalayan southward to Sri Lanka, Indonesia, Philippines, Malaysia, and eastward to Thailand and Indochina [6-9]. It is mainly distributed in primary and secondary evergreen forest, but can be found in mixed-deciduous and deciduous forests, swamp forest, and cloud forest as well. In addition, it is mostly found at the elevation of about 1000 to $2000 \mathrm{~m}$ [7]. According to the IUCN Red List of Threatened Species 2017, assessed by Barstow and Rehel [9], M. lunu-ankenda is currently categorized as Least Concern (LC) due to its wide geographical distribution, but the threats from timber harvesting may reduce its population size.

\subsection{Taxonomy of Melicope lunu-ankenda}

According to Hartley [7], the name of lunu-ankenda is derived from Sinhalese language lunu (salt) and ankenda (horny fiber), referring to the plant's occurrence at sea level and its cartilaginous endocarp. Besides, ankenda is also the Sinhalese name for Acronychia pedunculata (L.) Miq.; thus, lunu-ankenda can be translated as "sea level Acronychia", since A. pedunculata has a cartilaginous endocarp as well.

According to Barstow and Rehel [9], the taxonomy of this species is as following in the Table 2.

Table 2. The taxonomy of M. lunu-ankenda [9].

\begin{tabular}{cc}
\hline Taxonomic Rank & Taxon \\
\hline Kingdom & Plantae \\
Phylum & Tracheophyta \\
Class & Magnoliopsida \\
Order & Sapindales \\
Family & Rutaceae \\
Genus & Melicope \\
Species & Melicope lunu-ankenda (Gaertn.) T.G. Hartley \\
\hline
\end{tabular}

Based on the information from Global Biodiversity Information Facility (GBIF) [10], the basionym of M. lunu-ankenda is Fagara lunu-ankenda Gaertn. Besides, there are synonyms for this plant species, such as:

- Euodia lunu-ankenda (Gaertn.) Merr.

- Euodia roxburghiana (Cham.) Benth.

- Evodia lunu-ankenda (Gaertn.) Merr. 
- Zanthoxylum aromaticum (Blume) Miq.

- Zanthoxylum roxburghianum Cham.

Euodia is the original and correct spelling used for the synonym for Melicope, while Evodia is the orthographical variant of Euodia [6].

\subsection{Morphology of Melicope lunu-ankenda}

M. lunu-ankenda is a shrub or tree that can grow up to about $30 \mathrm{~m}$ tall. The leaves are opposite, trifoliolate, unifoliolate (uncommon) or quadri or pentafoliolate (rare), and leaflets are elliptic or obovate-shaped. The inflorescences are axillary, the flowers are unisexual and bisexual (rare), the sepals are round to ovate-triangular shaped, and the petals are ovate to elliptic. Next, the fruiting carpels that connate at the base are ellipsoid to obovoid in shape, and the shape of the seeds is round to ovoid or ellipsoid, but are compressed occasionally [3,7].

\section{Melicope in Folk Usage}

Many species from the genus Melicope have been used for decades in folk medicine traditions for healthcare purposes, including treatment for diseases and disorders. Here are some examples of Melicope species that have been used in folklore medicinal practices.

In China, the fruits of Evodia rutaecarpa have been used for the treatment of headaches, abdominal pain, postpartum hemorrhage, amenorrhea, and dysentery [11]. In Bangladesh, the raw stem of M. anisata is rubbed on the gum and teeth as toothpaste for oral hygiene [12].

M. pteleifolia (Champ. ex Benth) T.G. Hartley, also known as Evodia lepta (Spreng.) Merr., is a species that is widely distributed in Vietnam and China. In Vietnam, the extract from M. pteleifolia, which is called ' $B a c_{c h a c}$ ', is used for the treatment of fevers, colds, and inflammatory conditions [13]. In Malaysia, it has been commonly used as a remedy for fever, emmenagogue, stomachache, rheumatism, wounds, and itches. In addition, it is used for lowering the blood pressure and preventing premature ejaculation [14].

M. borbonica, also known as Euodia borbonica var. borbonica, is a species that is endemic to Réunion Island, France. It has been used for wound-healing, blood-cleansing, and as a sudorific drug. It is also used for its aromatic properties and treatment of rheumatism [15].

In Papua New Guinea, the decoction prepared from the dried bark of M. elleryana, which is also known as Euodia elleryana F. Muell., is used for the treatment of malaria. The juice squeezed from its fresh bark is used as a contraceptive, whose effect is reported to last for two to three years. In addition, the dried leaves of M. triphylla (Euodia anisodora) are heated, and the sap is consumed to treat tuberculosis. Besides, the leaves are used with the leaves, bark, and fruit of Citrus for treating constipation, diarrhea, stomach pain, and removing intestinal worms [16].

M. confusa or its synonym as Euodia confusa, is mostly distributed in Borneo, the Philippines, and part of Indonesia. In the Philippines, its bark is used for treating spleen enlargement. In Taiwan, its root decoction or leafy shoot mixed with liquor is consumed to cure hives [3].

In Indonesia, the bark of M. bonwickii (Euodia bonwickii) is used in treating bites caused by leeches. The leaves of M. latifolia (Euodia latifolia) are used for the treatment of fever and cramps in Indonesia and peninsular Malaysia, and its resin is used as varnish and adhesive [3].

M. madagascariensis (Evodia madagascariensis) is the plant species endemic to Madagascar. Its crushed roots are used for wound-healing. The infusion of its stem bark is used to treat measles, and aromatic essential oil is distilled from its leaves for massages [17].

In Malaysia, M. lunu-ankenda is locally known as "tenggek burung" [18]. The leaves are consumed as salad and condiment for food flavoring, as well as traditionally used to revitalize the body [19-21]. The flowers are also being consumed to control the conditions of diseases and disorders, including hypertension, menstrual disorder, and fever $[19,21]$. The roots are used for the treatment of colds and rheumatism, and the timber is used in construction [19]. It is also used to treat diabetes. In India, 
different parts of the plant are used for treatment for fever, the improvement of complexion, and as an emmenagogue and tonic. The leaves are utilized for the treatment for diabetes in folklore medicinal practices [18]. In Eastern Ghats, one of the nine Floristic Zones in India, the decocted root is used to treat asthma and bronchitis by mixing with black pepper and salt [22].

\section{Phytochemical Compounds Isolated from Melicope lunu-ankenda}

According to Al-Zuaidy et al. [23], the leaf extract of M. lunu-ankenda is enriched with four major bioactive components, called isorhamnetin, skimmianine, scopoletin, and melicarpinone, which may attribute towards the antidiabetic and antioxidant activities in this species. O-prenylated flavonoid (3,5,4'-trihydroxy-8,3'-dimethoxy-7-(3-methylbut-2-enoxy) flavone), a molecule isolated from the leaves of M. lunu-ankenda, has been revealed to have antidiabetic activity [18]. Two quinoline alkaloids, buchapine and 3-(3-methyl-2-butenyl)-4-[(3-methyl-2-butenyl)oxy]-2(1H)-quinolinone, and three furoquinoline alkaloids, roxiamines $\mathrm{A}, \mathrm{B}$, and $\mathrm{C}$ were isolated from flowers, leaves, and twigs and it was revealed that only quinoline alkaloids possess anti-HIV inhibitory activity [24]. Ramli et al. [19] also found that the leaf extracts from $M$. lunu-ankenda contain mixtures of hydrocarbons and squalene, fatty acids, and esters. The same study revealed that dichloromethane and methanol from the crude extracts of leaves have very strong insecticidal activity. In addition, a $p$-coumaric acid derivative called $p$-O-geranylcoumaric acid or 3-\{4-O-(3,7-dimethyl-2,6-octadienyl) phenyl\}-2-propenoic acid, which is a geranylated coumaric acid, was isolated as the major compound of the leave extracts of M. lunu-ankenda [19].

Next, two major chromene-type compounds in the volatile oil and extracts, evodione and leptonol, have been shown to be biologically active. Leptonol demonstrated good antipyretic and antioxidant activities, while both chromenes showed moderate analgesic and anti-inflammatory activities, rationalizing the use of $M$. lunu-ankenda in treating conditions such as fever and inflammation in folklore practices [8]. Furoquinoline alkaloids, dictamnine, evolitrine, kokusaginine, and N-methyl-4-methoxy-2-quinolone, along with marmesin, were also successfully isolated from the basic fraction of bark extract [25]. Furthermore, dictamnine (4-methoxyfuro[2,3-b]quinoline) and evolitrine (4,7-dimethoxyfuro[2,3-b]quinoline), which were isolated from the bark of M. lunu-ankenda, were reported to have moderate antifeedant activity [26]. Lal et al. [27] found that evolitrine, which was isolated from the dichloromethane extract of M. lunu-ankenda twigs, and some of its derivatives (alkoxy, amino, and dihydro derivatives) were demonstrated to have anti-inflammatory activity. The flower oil of $M$. lunu-ankenda was found to contain mostly evodione, (E)- $\beta$-ocimene, isolycodolin, and alloevodionol, as well as have significant antibacterial activity [28]. Moreover, 8-acetyl-3,4-dihydroxy-5,7-dimethoxy-2,2-dimethylchroman, along with alloevodionol-7-methyl ether, 4-methoxy-1-methyl-2(1H)-quinolinone, evolitrine, isoevodionoland its methyl ether were isolated from ethanolic extracts of the aerial parts of M. lunu-ankenda [29].

In addition, Kumar et al. [30] isolated three phenylethanones (1- $\left[2^{\prime}, 4^{\prime}\right.$-dihydroxy- $3^{\prime}, 5^{\prime}-\operatorname{di}\left(3^{\prime \prime}-\right.$

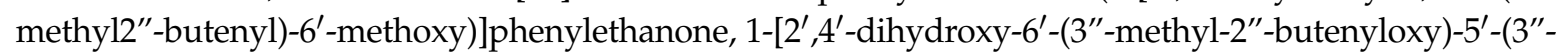
methyl-2"-butenyl)]phenylethanone, and 1-[2', $4^{\prime}$-dihydroxy-6'-(3", $7^{\prime \prime}$-dimethylocta-2" $6^{\prime \prime} 6^{\prime \prime}$-dienyloxy)-5'(3"-methyl-2"-butenyl)]phenylethanone), five furoquinoline alkaloids (dictamine, evolitrine, $\gamma$-fagarine, skimmianine, and kokusaginine), lupeol and bergapten from the root bark of M. lunu-ankenda. Besides, Ito et al. [31] isolated two new coumarins, melilunumarin A (7-(4-hydroxy-3-methylbutanoxy) coumarin) and melilunumarin B (7-(3-methyl-4-carboxybutanoxy) coumarin methyl ester), and a new benzaldehyde derivative, 3,4-dihydro-3,4-dihydroxy-2,2-dimethyl-2H-1-benzopyran-6-carboxaldehyde, named melilunumane, from M. lunu-ankenda. They also isolated 6-deoxyhaplopinol, marmesin, umbelliferone, kokusaginine, and evolitrine. Among them, melilunumarin A, 6-deoxyhaplopinol, and marmesin were shown to have inhibitory activity to Epstein-Barr virus (EBV), a herpesvirus known to be associated with cancers such as nasopharyngeal carcinoma (NPC) [31,32].

Table 3 shows the group, chemical structure, and biological activity of some of the phytochemical compounds isolated from M. lunu-ankenda. 
Table 3. The group, chemical structure, and biological activity of some phytochemical compounds in M. lunu-ankenda.

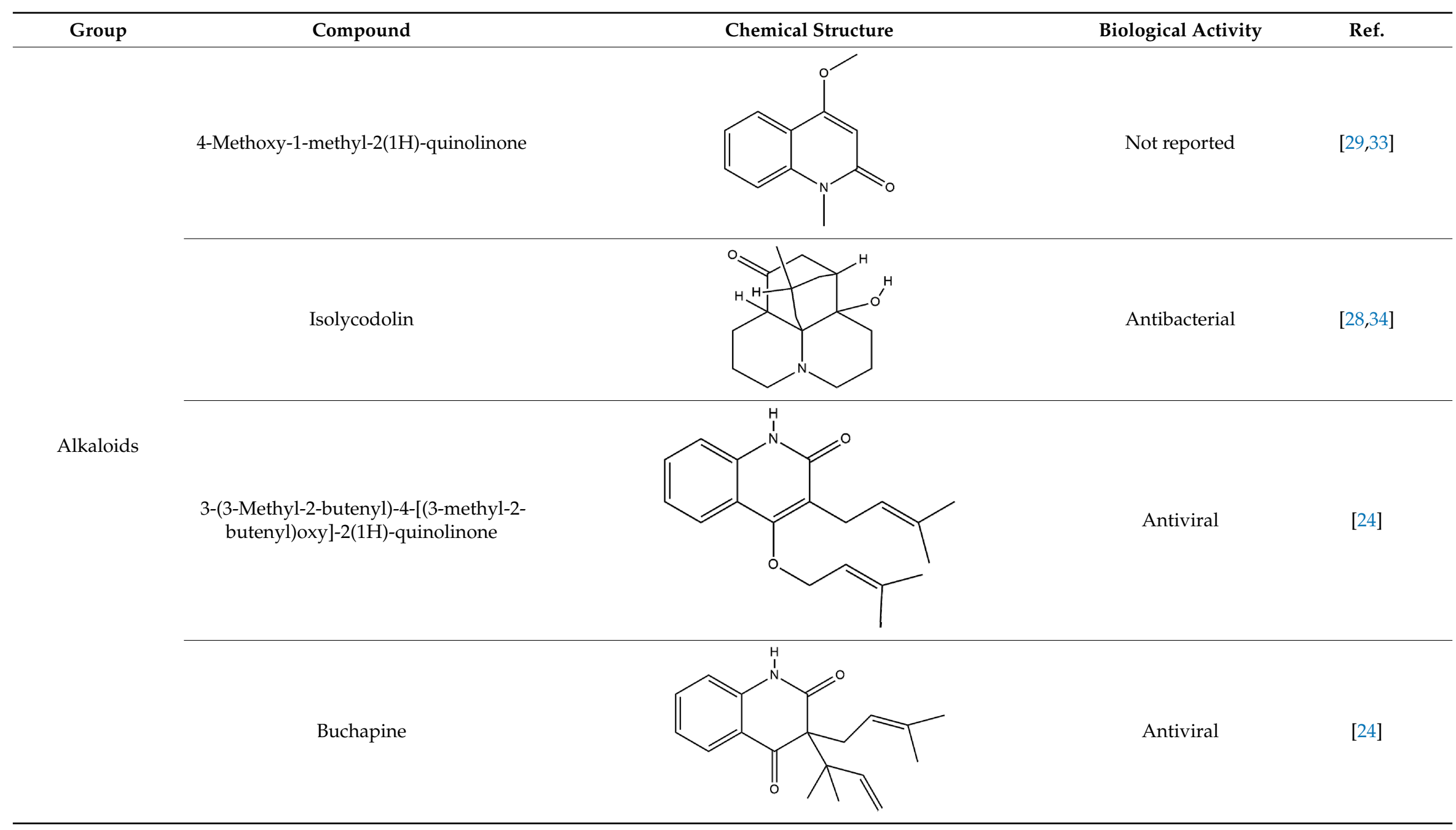


Table 3. Cont

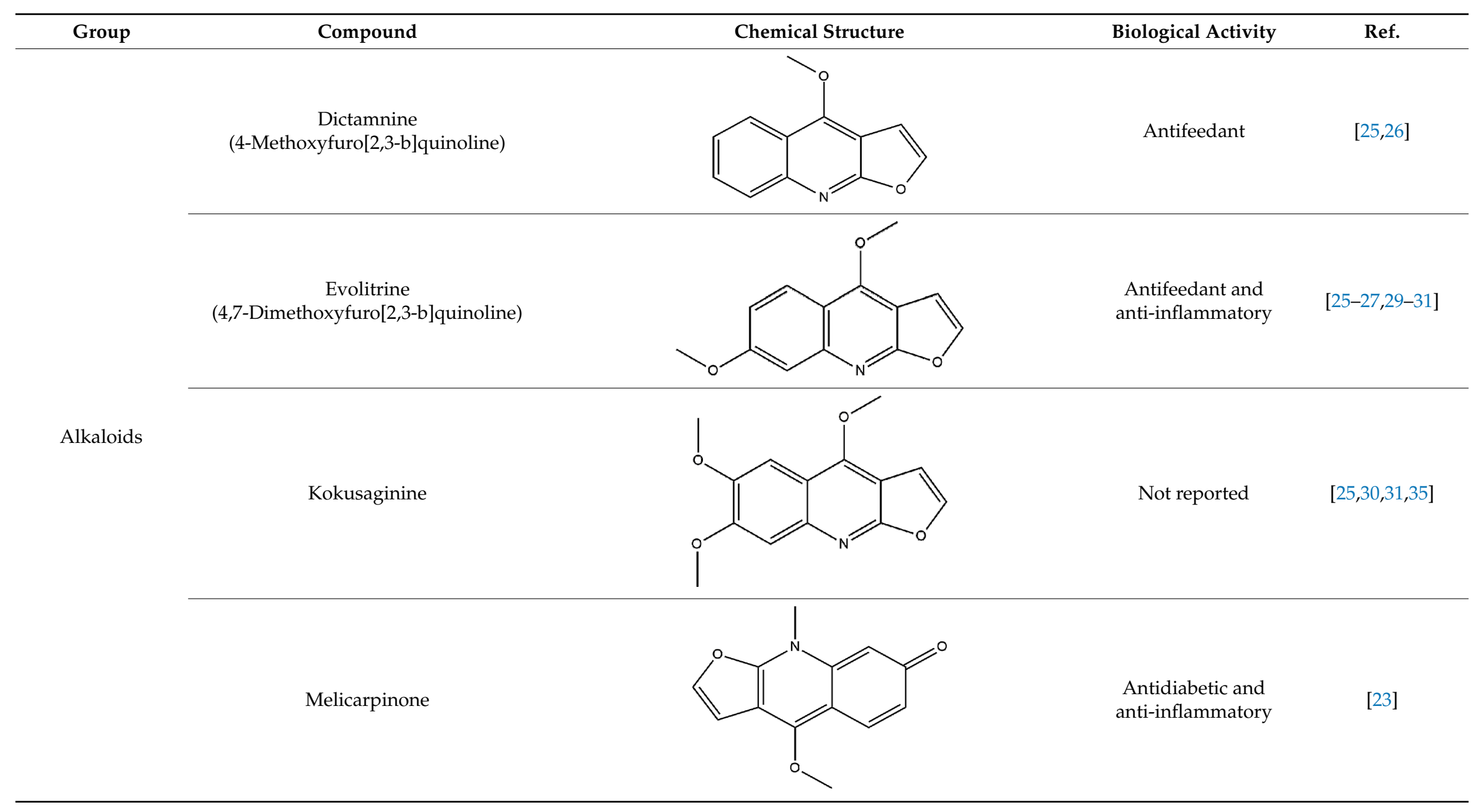


Table 3. Cont

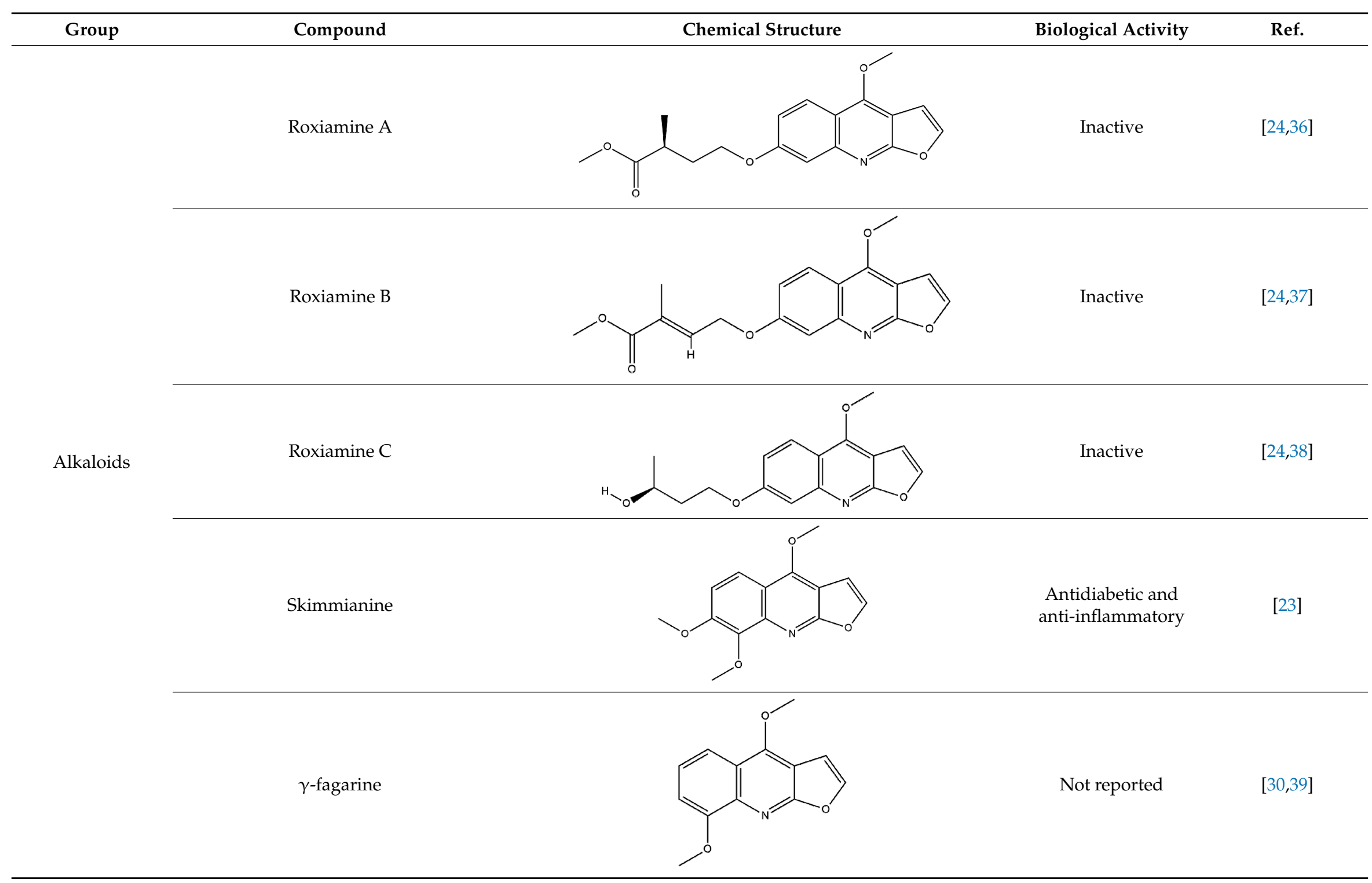


Table 3. Cont

\begin{tabular}{|c|c|c|c|c|}
\hline Group & Compound & Chemical Structure & Biological Activity & Ref. \\
\hline \multirow{5}{*}{ Chromenes } & Alloevodionol & & Antibacterial & {$[28,40]$} \\
\hline & Evodione & & $\begin{array}{l}\text { Analgesic, } \\
\text { anti-inflammatory, } \\
\text { and Antibacterial }\end{array}$ & {$[8,28]$} \\
\hline & Isoevodionol & & Not reported & {$[29,41]$} \\
\hline & Leptonol & & $\begin{array}{l}\text { Antipyretic, } \\
\text { antioxidant, } \\
\text { analgesic, and } \\
\text { anti-inflammatory }\end{array}$ & [8] \\
\hline & $\begin{array}{c}\text { Melilunumane } \\
\text { (3,4-Dihydro-3,4-dihydroxy-2,2-dimethyl- } \\
\text { 2H-1-benzopyran-6-carboxaldehyde) }\end{array}$ & & Not reported & [31] \\
\hline
\end{tabular}


Table 3. Cont

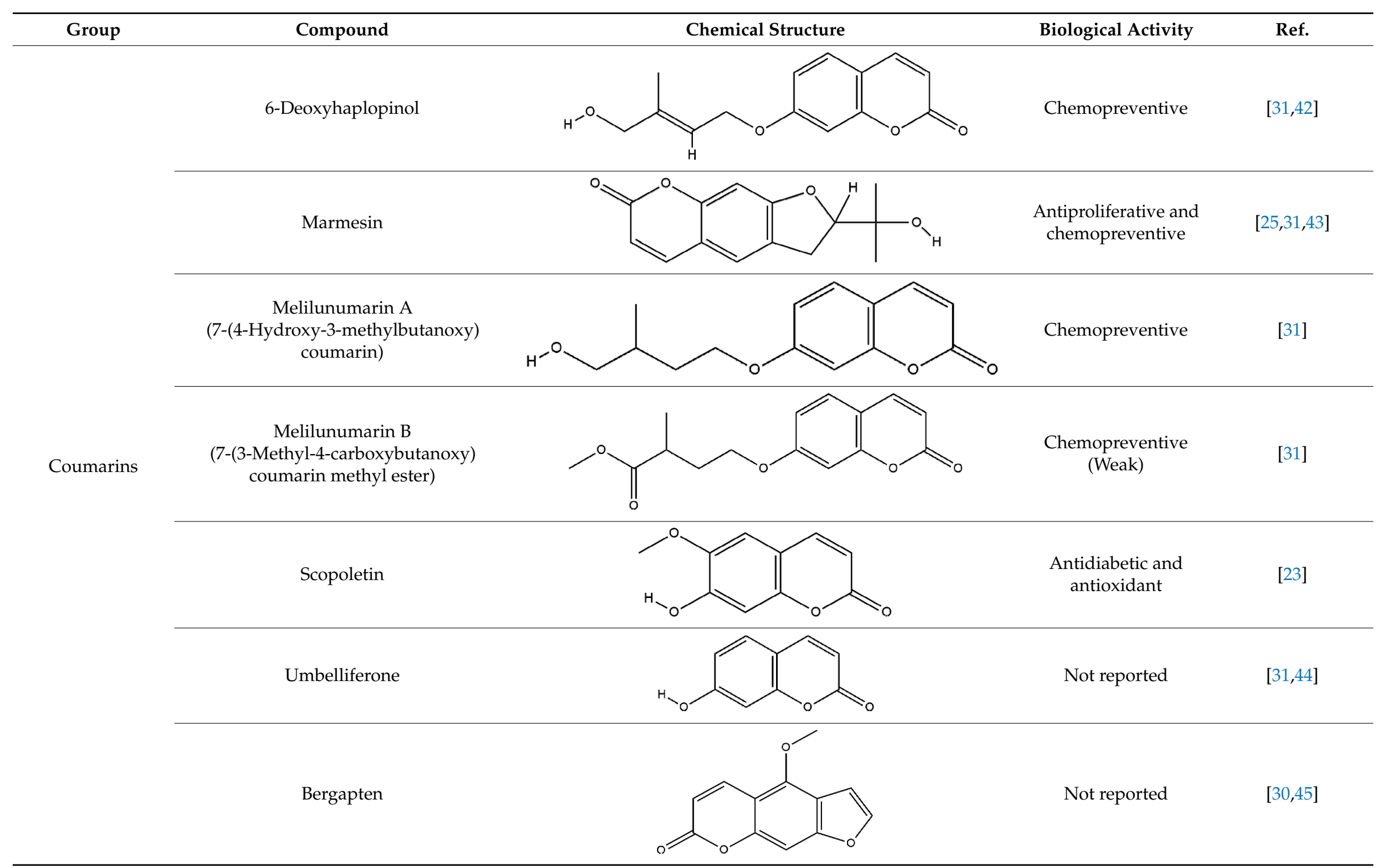


Table 3. Cont

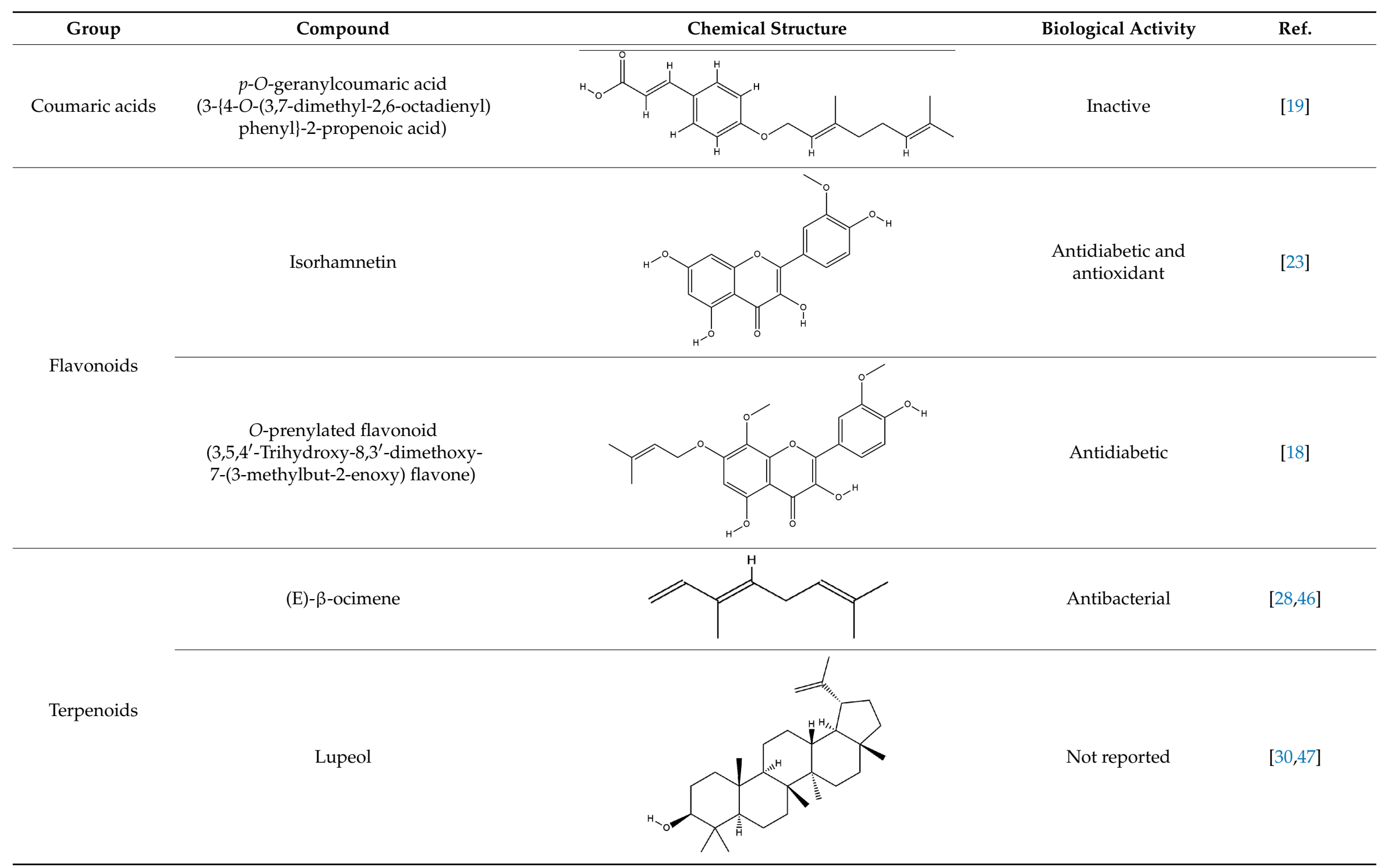




\section{Biological Activities of Melicope lunu-ankenda}

The phytochemical compounds isolated from extracts of various parts of M. lunu-ankenda have been demonstrated to have many different biological activities including antioxidant, antidiabetic, analgesic, and antibacterial activities. Not only do these biological activities justify the use of the plant in folklore practices, they also indicate its great potential and economical value in food and health industries. Each biological activity of M. lunu-ankenda is described below.

\subsection{Analgesic}

Lalitha et al. [48] reported that the ethyl acetate extracts of the bark of M. lunu-ankenda showed analgesic activity at both $500 \mathrm{mg} / \mathrm{kg}$ and $1000 \mathrm{mg} / \mathrm{kg}$ concentrations, as the time Swiss albino mice reacted to pain stimulus was increased in both Eddy's hot plate and heat conduction methods. Its activity is equipotent to standard analgesic drugs morphine sulfate, which was injected to mice at $5 \mathrm{mg} / \mathrm{kg}$ for comparison (standard), justifying the effectiveness and the use of this plant species as an analgesic drug. Besides, the extracts were non-toxic up to $3000 \mathrm{mg} / \mathrm{kg}$ body weight of the tested mice. However, the phytochemical profile of the extract is yet to be elucidated. Furthermore, evodione and leptonol were also proven to show moderate analgesic activity in acetic acid-induced writhing and tail immersion assays [8]. Both evodione and leptonol were administrated orally to mice at $50 \mathrm{mg} / \mathrm{kg}$ and $100 \mathrm{mg} / \mathrm{kg}$ for both assays, respectively. In the acetic acid-induced writhing assay, leptonol and evodione at $100 \mathrm{mg} / \mathrm{kg}$ demonstrated $53.6 \%$ and $56.7 \%$ inhibition respectively as compared to $75.6 \%$ inhibition showed by aspirin, which was used positive control in the assay. In tail immersion assay, the mice's response times were $5.71 \pm 0.04 \mathrm{~s}$ and $6.05 \pm 0.05 \mathrm{~s}$ for leptonol and evodione respectively at $100 \mathrm{mg} / \mathrm{kg}$, while aspirin $(100 \mathrm{mg} / \mathrm{kg})$ was $7.59 \pm 0.07 \mathrm{~s}$ [8].

\subsection{Anthelmintic}

Venkatachalam et al. [49] found that both bark ethyl acetate and aqueous extracts of $M$. lunu-ankenda demonstrated anthelmintic activity in a dose-dependent manner $(25 \mathrm{mg} / \mathrm{mL}, 50 \mathrm{mg} / \mathrm{mL}$, and $100 \mathrm{mg} / \mathrm{mL}$ ) in both Eudrillus eugeniae (earthworm) and Ascaris lumbricoids (roundworm), respectively. Besides, they found that the bark ethyl acetate extract of this plant species showed the most potent anthelmintic activity at $100 \mathrm{mg} / \mathrm{mL}$ among different doses applied to both earthworm and roundworm. The activity is comparable to the activity by standard drug Albendazole. Both earthworm and roundworm were used, because they have anatomical and physiological similarities with human intestinal earthworm and roundworm parasite. However, the phytochemical compounds that are responsible for the activity have yet to be determined.

\subsection{Antibacterial}

Quorum sensing (QS) is an ability that Gram-negative bacteria use to coordinate the population behavior, including virulence factors expression via extracellular signaling molecules, such as $N$-acyl-L-homoserine lactones (AHLs). QS involves the coupling of AHLs to a transcriptional activator that modulates QS-mediated gene expression [20]. According to Tan et al. [20], they found that M. lunu-ankenda has anti-QS properties, as its extracts inhibited the QS-dependent virulence determinants of human pathogens called Pseudomonas aeruginosa PAO1. However, the anti-QS compound in the extracts has yet to be identified, but it proved that endemic plants in Malaysia could become leads in searching for anti-QS compounds.

Sabulal et al. [28] reported that the flower oil of M. lunu-ankenda exhibited significant in vitro antibacterial activity against all of the tested Gram-negative and Gram-positive bacteria, especially against Salmonella typhi and Klebsiella pneumoniae, which are both Gram-negative bacteria. They found that the major constituents of the flower oil are evodione (38.9\%), (E)- $\beta$-ocimene (12.4\%), isolycodolin $(11.7 \%)$, and alloevodionol (10.6\%), which all take up more than $70 \%$ of the content of the oil. However, the mechanism of the antibacterial activity of the oil was not reported in this study. 
Moreover, Manandhar et al. [29] found that among the compounds isolated from ethanolic extracts of M. lunu-ankenda, 8-acetyl-3,4-dihydroxy-5,7-dimethoxy-2,2-dimethylchroman, alloevodionol7-methyl ether, evolitrine, 4-methoxy-1-methyl-2(1H) quinolinone and its isomer were revealed to demonstrate antibacterial activities against Bacillus subtilis and Staphylococcus aureus. The minimum inhibitory concentrations (MICs) for each of the compounds mentioned are $250 \mu \mathrm{g} / \mathrm{mL}, 250 \mu \mathrm{g} / \mathrm{mL}$, $62.5 \mu \mathrm{g} / \mathrm{mL}, 250 \mu \mathrm{g} / \mathrm{mL}$, and $250 \mu \mathrm{g} / \mathrm{mL}$ respectively. Nonetheless, the mechanisms or functions of those compounds that are involved in antibacterial activity were not reported as well.

\subsection{Cytotoxic Activity/Chemopreventive Effect}

AL-Zuaidy et al. [50] reported the cytotoxic potential of the leaf extract (60\% ethanolic extract) of M. lunu-ankenda on 3t3-L1 (mouse preadipocytes) and HepG2 (hepatocellular carcinoma). Their results showed that the extract showed potent cytotoxic activity against HepG2 cells with $\mathrm{IC}_{50}$ of $20.33 \pm 1.5 \mu \mathrm{g} / \mathrm{mL}$ and $13.7 \pm 2.1 \mu \mathrm{g} / \mathrm{mL}$ after the exposure for $48 \mathrm{~h}$ and $72 \mathrm{~h}$ respectively by using MTT assay. On the other hand, the same extract was also found to be in minimal activity against 3t3-L1 cell with the $\mathrm{IC}_{50}$ of $143.7 \pm 3.2 \mu \mathrm{g} / \mathrm{mL}, 93 \pm 3 \mu \mathrm{g} / \mathrm{mL}$, and $81 \pm 2 \mu \mathrm{g} / \mathrm{mL}$ after exposure for three different respective time points: $24 \mathrm{~h}, 48 \mathrm{~h}$, and $72 \mathrm{~h}$. This shows that the leaf extract is cytotoxic to cancer cells, and leaves the normal, non-cancerous cells unaffected. Their findings also suggested the significance of M. lunu-ankenda as a medicinal plant and as an antiproliferative agent. They suggested that the cytotoxicity of the extract may be attributed to the phytochemicals, especially the alkaloids in the extract.

In addition, Ito et al. [31] found that three coumarins, melilunumarin A, 6-deoxyhaplopinol, and marmesin showed a significant chemopreventive effect on Epstein-Barr virus early antigen (EBV-EA) activation with $\mathrm{IC}_{50}$ of $303 \mathrm{~mol}$ ratio/TPA, $300 \mathrm{~mol}$ ratio/TPA. and $336 \mathrm{~mol}$ ratio/TPA respectively, by using a short-term in vitro assay of TPA-induced EBV-EA activation in Raji cells. These $\mathrm{IC}_{50}$ values are comparable to curcumin ( $\mathrm{IC}_{50} 341 \mathrm{~mol}$ ratio/TPA) EBV is a $\gamma$-herpesvirus that is associated with human malignancies, such as Burkitt's lymphoma (BL), nasopharyngeal carcinoma (NPC), and T-cell lymphoma [32]. Their findings suggested that the relative location of a hydroxy group and a hydrophobic prenyl moiety in coumarin may contribute to the chemopreventive effect of the compound against chemical-induced malignancy such as TPA [31]. Table 4 shows the functions or mechanisms of compounds contributing to the cytotoxic/chemopreventive activity of M. lunu-ankenda. Figure 1 demonstrates the mechanism of marmesin cytotoxic/chemopreventive activity.

Table 4. Brief description of functions or mechanisms of extracts and compounds isolated from M. lunu-ankenda.

\begin{tabular}{|c|c|c|c|}
\hline Extract/Compound & Cancer Cell & Function/Mechanism & Ref. \\
\hline $60 \%$ ethanolic extract & HepG2 & - $\quad$ Exhibit cytotoxicity without affecting normal cell line (3t3-L1) & [50] \\
\hline Melilunumarin A & \multirow{2}{*}{ Raji } & \multirow{2}{*}{$\begin{array}{l}\text { - Inhibit the TPA-induced Epstein-Barr virus early antigen } \\
\text { (EBV-EA) activation }\end{array}$} & \multirow{4}{*}{ [31] } \\
\hline 6-deoxyhaplopinol & & & \\
\hline \multirow{3}{*}{ Marmesin } & A549 & \multirow{2}{*}{$\begin{array}{ll}- & \text { Inhibit cell proliferation } \\
\text { - Inhibit the TPA-induced Epstein-Barr virus early antigen } \\
\text { (EBV-EA) activation }\end{array}$} & \\
\hline & KB & & \\
\hline & $\begin{array}{c}\text { HUVECs, } \\
\text { A549 \& H1299 }\end{array}$ & $\begin{array}{l}\text { - } \quad \text { Inhibit VEGF-A-stimulated endothelial cell proliferation } \\
\text { - } \\
\text { - } \\
\text { - }\end{array}$ & {$[51,52]$} \\
\hline
\end{tabular}




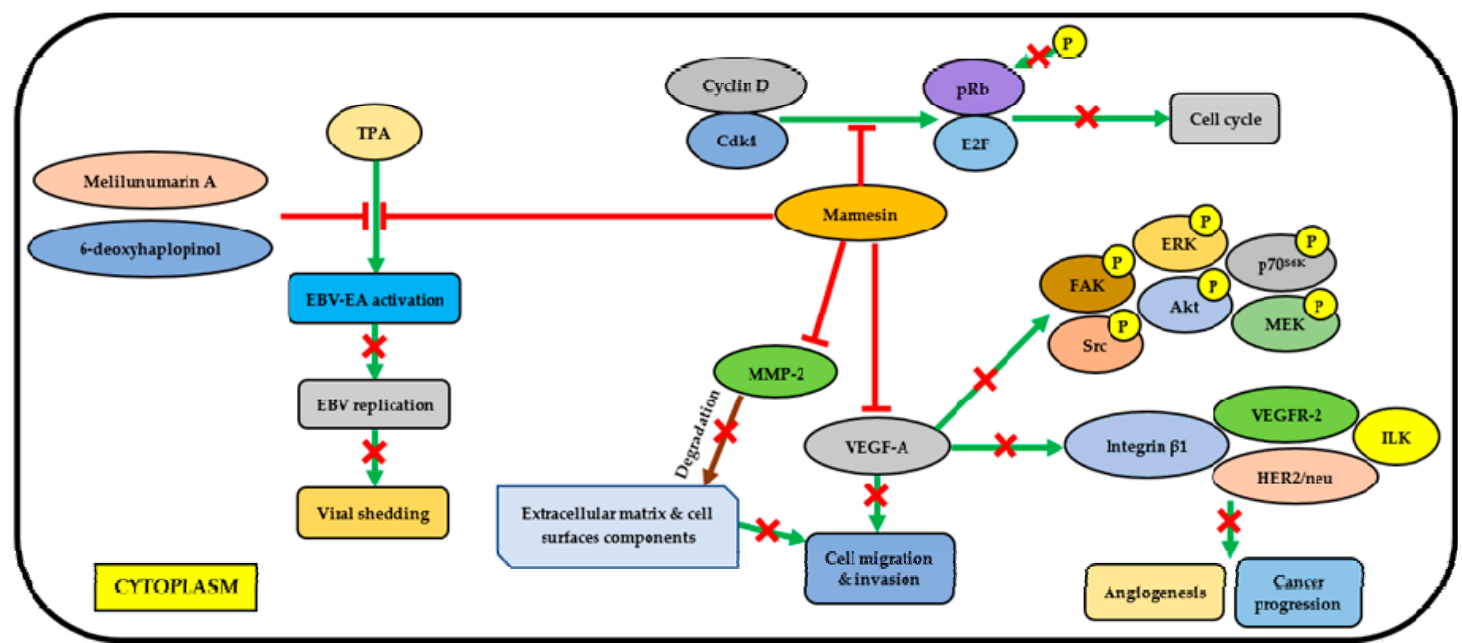

Figure 1. The mechanisms of cytotoxic/chemopreventive activity exhibited by marmesin. TPA, 12-Otetradecanoylphorbol-13-acetate; EBV-EA, Epstein-Barr virus early antigen; Cdk, cyclin-dependent kinase; $\mathrm{pRb}$, retinoblastoma protein; E2F, transcription factor E2F; P, phosphate; MMP-2, matrix metalloproteinase-2; VEGF-A, vascular endothelial growth factor A; FAK, focal adhesion kinase; Src, proto-oncogene tyrosine-protein kinase; ERK, extracellular signal-regulated kinase; Akt, protein kinase B; p70S6K, ribosomal protein S6 kinase beta-1; MEK, mitogen-activated protein kinase kinase; VEGFR-2, vascular endothelial growth factor receptor-2; ILK, integrin-linked kinase; HER2/neu, human epidermal growth factor receptor 2.

Marmesin, melilunumarin A, and 6-deoxyhaplopinol were found to demonstrate inhibitory effect on TPA-induced EBV-EA activation in Raji cells [31]. Besides, marmesin inhibits pRb phosphorylation in human umbilical vein endothelial cells (HUVECs) and in non-small cell lung cancer (NSCLC) cell lines (A549 and H1299) by suppressing the expression of Cdk4 and cyclin D; hence, the cell cycle is halted [51,52]. It suppresses the expression and activity of MMPs (MMP-2) to prevent cell migration and invasion, which can also be prevented by inhibiting VEGF-A [51]. In addition, marmesin significantly inhibits the VEGF-A-induced phosphorylation of FAK, Src, ERK, Akt, p70 ${ }^{\mathrm{S} 6 \mathrm{~K}}$ and MEK, and expression of cellular signaling molecules including vascular endothelial growth factor receptor-2 (VEGFR-2), human epidermal growth factor receptor 2 (HER2/neu), integrin $\beta 1$ and integrin-linked kinase (ILK), which are closely associated with angiogenesis and cancer progression [51,52].

\subsection{Antidiabetic}

It is known that diabetes mellitus (DM) is the result of oxidative stress caused by the imbalance between antioxidant defenses and production of reactive oxygen species (ROS). The stress can be increased by increasing the generation of ROS and/or reducing the elimination of ROS by antioxidant. As a result, DM arises due to the excessive production of ROS and impairment of the antioxidant defense system. Thus, a compound that inhibits the oxidative stress will be regarded as an antioxidant [23].

According to Al-Zuaidy et al. [23], four major bioactive compounds-isorhamnetin, scopoletin, skimmianine, and melicarpinone-were found in the ethanolic leaf extracts of M. lunu-ankenda. The functions of these compounds are briefly described in Table 5. By using the inhibition of the $\alpha$-glucosidase assay, they found that $40 \%, 60 \%$, and $80 \%$ ethanolic extracts showed significant antidiabetic activity with $\mathrm{IC}_{50}$ of $41 \mu \mathrm{g} / \mathrm{mL}, 37 \mu \mathrm{g} / \mathrm{mL}$, and $39 \mu \mathrm{g} / \mathrm{mL}$, respectively. Their findings also revealed that $60 \%$ ethanolic extract showed the highest inhibitory effect against $\alpha$-glucosidase among the other extracts of different concentrations. Besides, 2,2-diphenyl-1-picrylhydrazyl (DPPH) assay was used to evaluate the radical scavenging potential of the extracts, and they found that all of the extracts of different concentrations demonstrated potent antioxidant effect, with $\mathrm{IC}_{50}$ of $48 \mu \mathrm{g} / \mathrm{mL}$ and $53 \mu \mathrm{g} / \mathrm{mL}$ for $60 \%$ and $80 \%$ ethanolic extracts, respectively. In addition, they also reported the in vivo antidiabetic 
effect of the extracts in experimented rats. The rats treated with extracts at $400 \mathrm{mg} / \mathrm{kg}$ body weight (BW) revealed a noticeable reduction in fasting blood glucose levels compared to diabetic rats, with the suppression in fasting blood glucose level by $62.75 \%$.

George et al. [18] successfully isolated 3,5,4'-trihydroxy-8,3'-dimethoxy-7-(3-methylbut-2-enoxy) flavone, a unique $\mathrm{O}$-prenylated flavonoid (OPF) from the petroleum ether extract of $M$. lunu-ankenda leaves. They found this compound significantly reduced the blood glucose level by using an oral glucose tolerance test on overnight fasted, glucose-loaded normal rats. They found that OPF at $10 \mathrm{mg} / \mathrm{kg}$ and $25 \mathrm{mg} / \mathrm{kg}$ body weight showed a significant reduction in blood glucose levels at $30 \mathrm{~min}$ and $90 \mathrm{~min}$ after glucose administration, with the activity of OPF at a dose of $10 \mathrm{mg} / \mathrm{kg}$ body weight, was taken as the optimum, as dose-dependent glucose-lowering activity was not exhibited for the compound at $25 \mathrm{mg} / \mathrm{kg}$ body weight. In neonatal streptozotocin (STZ)-induced diabetic rats, the blood glucose levels reduced $(98.1 \pm 2.4 \mathrm{mg} / \mathrm{dL})$, and were comparable to control after 20 days of OPF treatment. Moreover, serum biochemical parameters (SGOT, SGPT, ALP, protein and serum insulin levels) in STZ-induced rats were restored to normal levels (91.9 $\pm 50 \mathrm{IU} / \mathrm{L}$, $23.4 \pm 4.1 \mathrm{IU} / \mathrm{L}, 12.9 \pm 1.5 \mathrm{KAU}, 7.1 \pm 1.0 \mathrm{~g} / \mathrm{dL}$, and $1.39 \pm 0.1 \mathrm{ng} / \mathrm{mL}$, respectively) when treated with OPF. Their findings also reported that a single dose of OPF at $500 \mathrm{mg} / \mathrm{kg}$ body weight did not exhibit any toxic symptoms in mice in acute toxicity study. They also conducted insulin release assay on cultured RIN 5F cells to elucidate the mechanism of OPF for its antidiabetic activity. The mechanism of OPF is briefly described in Table 5 .

The findings rationalized the use of M. lunu-ankenda for diabetic treatment in folk medicine tradition, and suggested that $M$. lunu-ankenda could be used for the development of new generation antidiabetic drugs. Figures 2 and 3 show the mechanisms of antidiabetic activities exhibited by isorhamnetin and scopoletin.

Table 5. Brief description of functions or mechanisms of compounds isolated from M. lunu-ankenda for antidiabetic activity. ARE: antioxidant response element; DPPH: 2,2-diphenyl-1-picrylhydrazyl; iNOS: inducible nitric oxide synthase; NO: nitric oxide; Nrf-2: nuclear factor erythroid 2-related factor 2; ROS: reactive oxygen species; STZ: streptozotocin; t-BHP, tert-butyl hydroperoxide; TBA: thiobarbituric acid.

\begin{tabular}{|c|c|c|}
\hline Compound & Function/Mechanism & Ref. \\
\hline \multirow{2}{*}{ Ethanolic extract } & - $\quad$ Inhibit $\alpha$-glucosidase activity (key enzyme in carbohydrate hydrolysis) & [23] \\
\hline & - $\quad$ Stimulate dose-dependent glucose uptake in both 3t3-L1 and HepG2 cells & [50] \\
\hline \multirow[t]{2}{*}{ Isorhamnetin } & $\begin{array}{l}\text { - } \quad \text { Protect hepatocytes against oxidative stress by activating Nrf2-ARE pathway } \\
\text { - } \quad \text { Block t-BHP induced ROS production and cell death } \\
\text { - Inhibit invasion and migration of gastric cancer cells } \\
\text { - Inhibit the expression of iNOS and the production of NO in } \\
\text { LPS-activated macrophages }\end{array}$ & [53] \\
\hline & $\begin{array}{l}\text { - } \\
\text { - } \\
\text { - } \\
\text { - }\end{array}$ & [54] \\
\hline \multirow[b]{2}{*}{ Scopoletin } & $\begin{array}{ll}\text { - } & \text { Reduce the levels of blood glucose and lipid in STZ-induced diabetic rats } \\
\text { - } & \text { Regenerate pancreatic- } \beta \text { cells slightly }\end{array}$ & [55] \\
\hline & $\begin{array}{l}\text { - } \quad \text { Reduce hyperthyroid and hyperglycemic conditions without hepatotoxic effects } \\
\text { - Inhibit hepatic lipid peroxidation } \\
\text { - Increase the activities of superoxide dismutase, catalase and glutathione } \\
\text { - } \quad \text { Decrease the levels of serum thyroid hormone and glucose } \\
\text { - } \quad \text { Reduce the activity of hepatic glucose-6-phosphatase }\end{array}$ & [56] \\
\hline Skimmianine & - $\quad$ Exhibit anti-inflammatory activity and in vitro antidiabetic effects & \multirow{2}{*}{ [23] } \\
\hline Melicarpinone & - $\quad$ Exhibit anti-inflammatory activity and in vitro antidiabetic effects & \\
\hline $\begin{array}{l}\text { 3,5, } 4^{\prime} \text {-trihydroxy-8, } 3^{\prime} \text {-dimethoxy-7- } \\
\text { (3-methylbut-2-enoxy) flavone (OPF) }\end{array}$ & $\begin{array}{l}\text { Induce insulin release by acting on pancreatic } \beta \text {-cells (cultured RIN 5F cells) to } \\
\text { reduce blood glucose levels, serum biochemical parameters and diabetic } \\
\text { complications in STZ-induced diabetic rats. }\end{array}$ & [18] \\
\hline
\end{tabular}




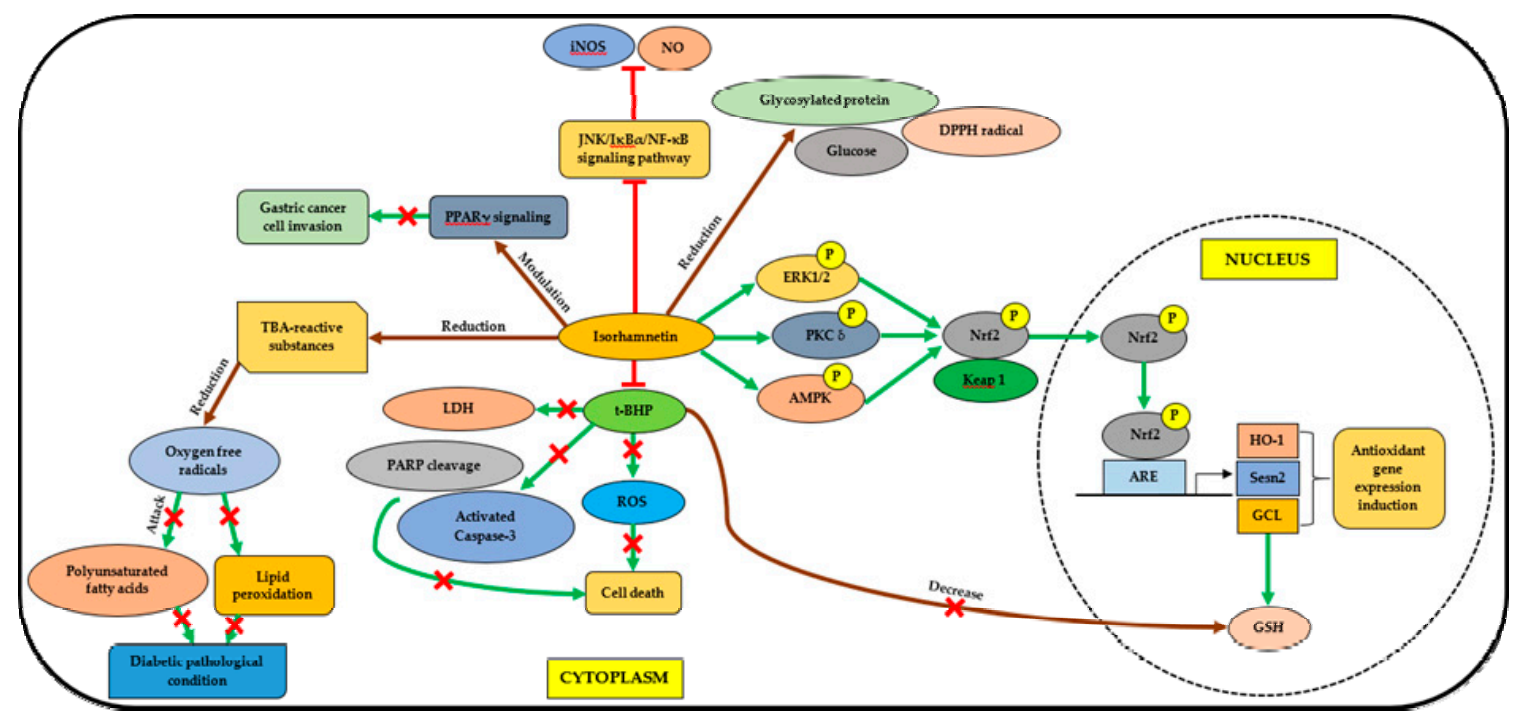

Figure 2. The mechanisms of antidiabetic activity exhibited by isorhamnetin. TBA, thiobarbituric acid; LDH, lactate dehydrogenase; PARP, poly (ADP-ribose) polymerase; ROS, reactive oxygen species; t-BHP, tert-butyl hydroperoxide; $\operatorname{PPAR} \gamma$, peroxisome proliferator-activated receptor gamma; JNK, c-Jun N-terminal kinase; $\mathrm{I} \kappa \mathrm{B} \alpha$, nuclear factor of kappa light polypeptide gene enhance in B-cells inhibitor, alpha; NF-kB, nuclear factor kappa-light-chain-enhancer of activated B cells; iNOS, inducible nitric oxide synthase; NO, nitric oxide; DPPH, 1,1-Diphenyl-2-picrylhydrazyl; ERK1/2, extracellular signal-regulated kinase 1 or 2 ; PKC $\delta$, protein kinase $C$ delta; AMPK, $5^{\prime}$ adenosine monophosphate-activated protein kinase; Nrf2, nuclear factor erythroid 2-related factor 2; Keap1, Kelch-like ECH-associated protein 1; ARE, antioxidant response element; HO-1, hemeoxygenase 1; Sesn2, sestrin2; GCL, glutamate-cysteine ligase; GSH, glutathione. Adapted from Yang et al. [53].

Isorhamnetin (in HepG2 cells) increases the nuclear translocation of Nrf2, decreases cytosolic nuclear factor erythroid 2-related factor 2 (Nrf2) in a dose-dependent manner, and consistently increases antioxidant response element (ARE) activity, and therefore, the induction of antioxidant gene expression such as hemeoxygenase 1 (HO-1), glutamate-cysteine ligase (GCL), and sestrin2 (Sesn2). The increase of glutathione (GSH) levels is suggested to be due to the induction of GCL expression [53]. Isorhamnetin can decrease the levels of glycosylated protein, glucose, and DPPH radicals as well as thiobarbituric acid (TBA)-reactive substances, which result in a reduction of oxygen free radical levels, and thus ameliorate the diabetic pathological condition [54]. The chemical is able to inhibit tert-butyl hydroperoxide ( $\mathrm{t}-\mathrm{BHP}$ )-induced reactive oxygen species (ROS) production and cell death (apoptosis), and reverse GSH depletion, as well as decrease the level of released lactate dehydrogenase (LDH). Furthermore, isorhamnetin was also found to inhibit gastric cancer cell invasion by modulating PPAR $\gamma$ signaling, and found to be suppressing inducible nitric oxide synthase (iNOS) expression and nitric oxide (NO) production in LPS-activated macrophages by inhibiting c-Jun N-terminal kinase (JNK)/nuclear factor of kappa light polypeptide gene enhance in B-cells inhibitor, alpha $(\mathrm{I} \kappa \mathrm{B} \alpha) /$ (nuclear factor kappa-light-chain-enhancer of activated B cells (NF- $\mathrm{B} B$ ) signaling pathway [53]. The pathway of Nrf2 nuclear translocation and the induction of expression of antioxidant genes are adapted from Yang et al. [53]. 


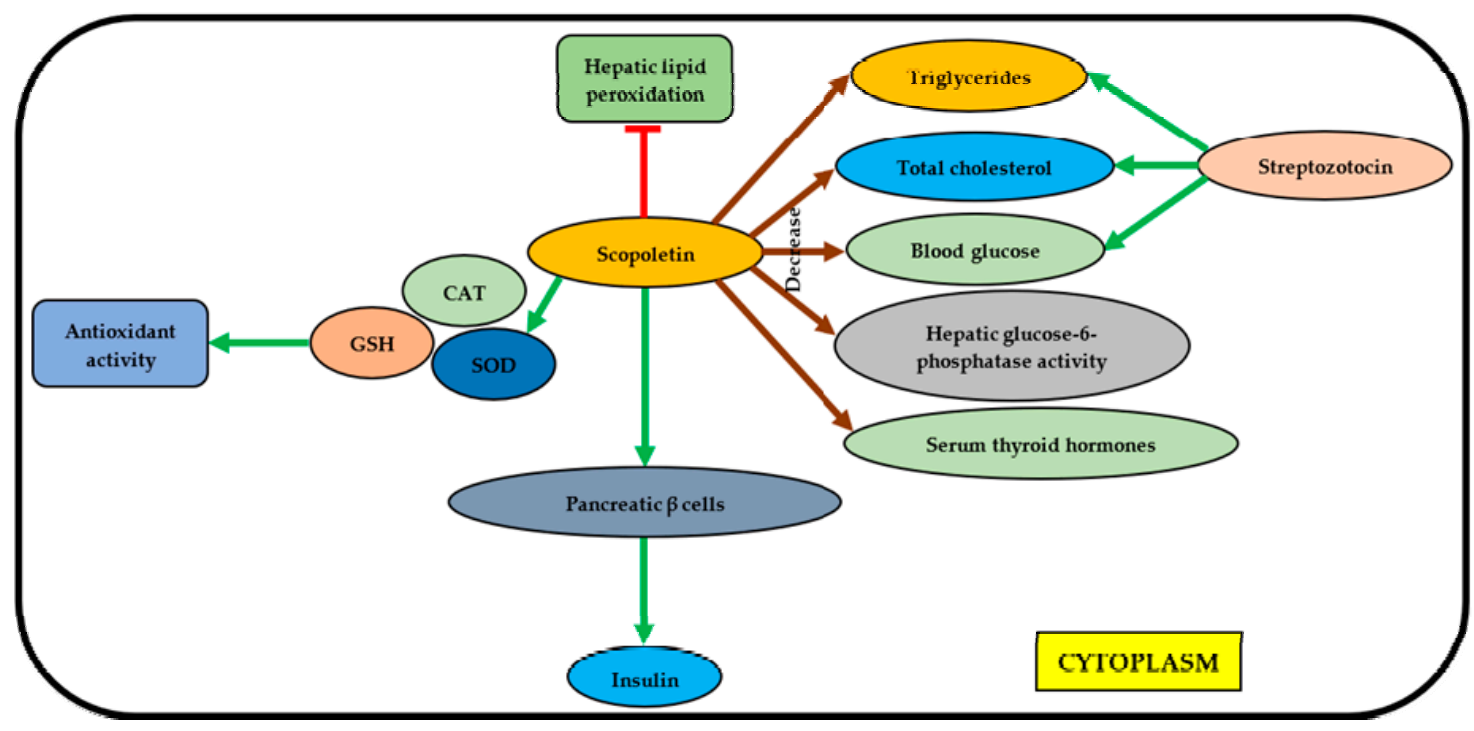

Figure 3. The mechanisms of antidiabetic activity exhibited by scopoletin. GSH, glutathione; CAT, catalase; SOD, superoxide dismutase.

Scopoletin was discovered to inhibit the hepatic lipid peroxidation (LPO) and able to increase the activity of antioxidants including superoxide dismutase (SOD), catalase (CAT) and glutathione (GSH) [56]. Besides, it was also to slightly regenerate pancreatic $\beta$ cells, thus secreting insulin. Moreover, scopoletin can decrease the activity of glucose-6-phosphatase and the levels of serum thyroid hormones, blood glucose, total cholesterol, and triglycerides, in which the levels of the last three molecules were increased by streptozotocin (STZ) $[55,56]$.

\subsection{Antifeedant}

According to Jagadeesh et al. [26], they found that dictamnine or 4-methoxyfuro[2,3- $b$ ]quinoline showed $62 \%$, and evolitrine or 4,7-dimethoxyfuro[2,3-b]quinoline showed $67 \%$ insect-antifeedant activities against agricultural pest tobacco caterpillar IV instar larvae Spodoptera litura in non-choice laboratory assay. Nevertheless, the mechanism of antifeedant activity was not reported.

\subsection{Anti-Inflammatory}

Two major chromene-type compounds isolated from the leaf oil of M. lunu-ankenda, evodione, and leptonol were discovered to have moderate anti-inflammatory activity against carrageenan-induced paw edema in rats. In both compounds, evodione was revealed to demonstrate better activity than leptonol with $59.4 \%$ and $49 \%$ inhibition of inflammatory reaction at $100 \mathrm{mg} / \mathrm{kg}$. This is also true for both compounds at $25 \mathrm{mg} / \mathrm{kg}$ and $50 \mathrm{mg} / \mathrm{kg}$, respectively. The positive control (indomethacin) showed $74 \%$ inhibition of inflammatory reaction at $10 \mathrm{mg} / \mathrm{kg}$ [8].

Lal et al. [27] reported that evolitrine could be an effective anti-inflammatory/immunomodulatory agent, as it effectively inhibited the carrageenan-induced rat paw edema. The percentage of inhibition of carrageenan-induced rat paw edema was found to increase significantly $(12 \%, 57 \%, 65 \%$, and $78 \%)$ as the dose of evolitrine increased $(10 \mathrm{mg} / \mathrm{kg}, 20 \mathrm{mg} / \mathrm{kg}, 40 \mathrm{mg} / \mathrm{kg}$, and $60 \mathrm{mg} / \mathrm{kg}$, respectively). A carrageenan-induced rat paw model in rat was used because it is the most relevant and widely used model for the prediction of the anti-inflammatory potentials of a drug in acute and chronic inflammatory conditions. They also reported that evolitrine is a more desirable anti-inflammatory agent, as it was found to be as potent as indomethacin (55\% inhibition of carrageenan edema at $5 \mathrm{mg} / \mathrm{kg}$ ), and does not cause gastric irritation. 


\subsection{Antioxidant}

Based on Johnson et al. [8], leptonol demonstrated moderate antioxidant activity in a dose-dependent manner in DPPH radical scavenging activity. The inhibitory percentage of DPPH radicals for leptonol is $68.75 \%$ at $500 \mu \mathrm{M}$. However, evodione showed almost no antioxidant activity $(1.36 \%$ inhibition), even at the dose of $500 \mu \mathrm{M}$. The similar result was also found in superoxide radical scavenging assay for the evaluation of antioxidant activity. They discovered that leptonol showed $64.46 \%$ of inhibition at $100 \mu \mathrm{g} / \mathrm{mL}$, while evodione showed $10.32 \%$ of inhibition at the same concentration. The positive control (quercetin) showed $66.87 \%$ inhibition at $10 \mu \mathrm{g} / \mathrm{mL}$. Both evodione and leptonol are the major chromene-type compounds that are found in M. lunu-ankenda.

Izzreen and Noriham [57] found that M. lunu-ankenda leaf extract, which was incorporated into the cakes and stored for 15 days at room temperature, showed the most potent antioxidant activity compared to formulations they used with leaf extracts from Polygonum minus (kesum) and Murraya koenigii (curry leaves). They found that the PV (peroxide value) in cakes treated with extract from M. lunu-ankenda was the lowest (not rancid and acceptable) for 15 days among all of the other plant extracts used (kesum and curry leaves). Besides, they found that the TBA (thiobarbituric acid) value in cakes added with extract of M. lunu-ankenda was below $1.0 \mathrm{mg} / \mathrm{kg}^{-1}$ sample (rancid but acceptable) up to 15 days. The antioxidant activity of extract from $M$. lunu-ankenda was revealed to be comparable to that of synthetic antioxidants (BHA/BHT), although BHA/BHT showed the strongest antioxidant activity throughout the storage period. Thus, it was suggested that the leaf extract of M. lunu-ankenda could be used in the food system as a natural antioxidant agent to extend the shelf life of food products. Nevertheless, their study did not determine the phytochemical composition of the leaf extract.

\subsection{Antipyretic}

Leptonol, which was isolated from the leaf oil of M. lunu-ankenda, has been shown to have good antipyretic activity with a reduction of $1.06^{\circ} \mathrm{F}$ of rat rectal temperature at a dose of $200 \mathrm{mg} / \mathrm{kg}$ after $90 \mathrm{~min}$ of the administration of the compound, which was comparable to the positive control acetaminophen $\left(-1.80^{\circ} \mathrm{F}\right.$ at $200 \mathrm{mg} / \mathrm{kg}$ at $\left.90 \mathrm{~min}\right)$. Meanwhile, the antipyretic activity for evodione was relatively low, with the rat rectal temperature reduced by $-0.47^{\circ} \mathrm{F}$ at $200 \mathrm{mg} / \mathrm{kg}$ at $90 \mathrm{~min}$ after the administration. The antipyretic activities for both evodione and leptonol were assayed by Baker's yeast-induced fever test [8]. However, more research is required to understand how both compounds can give rise to the antipyretic activity of $M$. lunu-ankenda.

\subsection{Antiviral}

According to McCormick et al. [24], buchapine and 3-(3-methyl-2-butenyl)-4-[(3-methyl-2-butenyl) oxy]-2(1H)-quinolinone were both found to be active against infectious HIV-1, as confirmed in an XTT-tetrazolium assay using human lymphoblastoid (CEM-SS) host cells (EC 50 of $0.94 \mu \mathrm{M}$, $\mathrm{IC}_{50}$ of $29 \mu \mathrm{M}$ and $\mathrm{EC}_{50}$ of $1.64 \mu \mathrm{M}, \mathrm{IC}_{50}$ of $26.9 \mu \mathrm{M}$, respectively). Besides, both compounds demonstrated inhibitory activity in an HIV-1 reverse transcriptase assay ( IC $_{50}$ of $12 \mu \mathrm{M}$ and $8 \mu \mathrm{M}$, respectively). This suggested that they might be potential candidates for anti-HIV agents. However, three furoquinoline alkaloids—roxiamines $\mathrm{A}, \mathrm{B}$, and $\mathrm{C}$ - were found to be inactive against HIV-1.

\subsection{Fungicidal}

Kumar et al. [30] found that two out of three phenylethanones, $1-\left[2^{\prime}, 4^{\prime}\right.$-dihydroxy- $6^{\prime}-\left(3^{\prime \prime}-\right.$

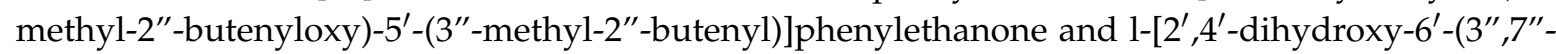
dimethylocta-2", $6^{\prime \prime}$-dienyloxy)-5'-(3"-methyl-2"-butenyl)]phenylethanone, demonstrated fungicidal activity. They newly isolated these two phenylethanones. 


\subsection{Insecticidal}

Based on the study by Ramli et al. [19], the larvicidal bioassay on the crude extracts (dichloromethane and methanol) of M. lunu-ankenda leaves revealed that both extracts showed high larvicidal (insecticidal) activity due to their very low $\mathrm{LC}_{50}$ values $(8.65 \mu \mathrm{g} / \mathrm{mL}$ and $12.63 \mu \mathrm{g} / \mathrm{mL}$, respectively). The same study also isolated a $p$-coumaric acid derivative, called $p$-O-geranylcoumaric acid (3-\{4-O-(3,7-dimethyl-2,6-octadienyl) phenyl\}-2-propenoic acid) with $\mathrm{LC}_{50}$ value of more than $100 \mu \mathrm{g} / \mathrm{mL}$, indicating very weak larvicidal activity. Besides, $p$-coumaric acid was demonstrated to have antibacterial activity as well, which kills bacteria through dual damage mechanisms: significantly increasing the permeability of the bacterial outer and plasma membrane, resulting in the loss of the barrier function and binding to bacterial genomic DNA to inhibit cellular functions, including replication, transcription, and expression [58].

\section{Conclusions}

Due to the increasing microbial resistance and side effects of synthesized drugs or medicine, herbs or medicinal plants are being given more attention than before. In addition, researchers found that the phytochemical compounds that were isolated from the herbs or medicinal plants are relatively safe and effective compared to chemically synthesized drugs or medicines. Melicope lunu-ankenda is one of the plant species that has been used in folklore medicinal practices for decades, especially in Asia, including Malaysia. Researchers have isolated various phytochemical compounds from different parts of M. lunu-ankenda, and they found that they demonstrated different beneficial biological activities such as analgesic, antidiabetic, cytotoxic, insecticidal, and antiviral activities. These findings not only justify the use of M. lunu-ankenda in folk medicine tradition but also indicate that it has potential in food and health industries.

Author Contributions: E.M.E., J.H.H. and A.F.A.R. designed the outline of the manuscript. E.M.E., J.H.H. and A.F.A.R. participated in literature collection and manuscript writing. E.M.E., J.H.H., N.M.H., Y.R., G.C.L.E. and A.F.A.R. reviewed and edited the manuscript. All authors finally reviewed and approved the manuscript.

Funding: This research received no external funding. The APC was paid by Universiti Putra Malaysia.

Acknowledgments: The authors express gratitude to the Malaysian Ministry of Education and Universiti Putra Malaysia for providing a research fund, research facilities and technical support. Also, thanks to Government of Libya for PhD scholarship (E.M.E).

Conflicts of Interest: The authors declare no conflict of interest.

\section{References}

1. Sasidharan, S.; Chen, Y.; Saravanan, D.; Sundram, K.M.; Yoga Latha, L. Extraction, isolation and characterization of bioactive compounds from plants' extracts. Afr. J. Tradit. Complement. 2011, 8, 1-10. [CrossRef]

2. Petrovska, B.B. Historical review of medicinal plants' usage. Pharmacogn. Rev. 2012, 6, 1-5. [CrossRef] [PubMed]

3. Jones, D.T. Rutaceae. In Tree Flora of Sabah and Sarawak; Soepadmo, E., Wong, K.M., Eds.; Ampang Press Sdn. Bhd.: Kuala Lumpur, Malaysia, 1995; Volume 1, pp. 351-419.

4. Abdul Karim, M.S.; Nasouddin, S.S.; Othman, M.; Mohd Adzahan, N.; Hussin, S.R.; Shaari, K. Consumers knowledge and perception towards Melicope ptelefolia (Daun Tenggek Burung): A preliminary qualitative study. Int. Food Res. J. 2011, 18, 1481-1488.

5. Hartley, T.G. Revision of the genus tetradium (Rutaceae). Gard. Bull. Singap. 1981, 34, 91-131.

6. Stone, B.C. Supplement to the rutaceae in peninsular Malaysia. Gard. Bull. Singap. 1994, 46, 121-140.

7. Hartley, T.G. On the taxonomy and biogeography of Euodia and Melicope (Rutaceae). Allertonia 2001, 8, 1-319.

8. Johnson, A.J.; Kumar, A.; Rasheed, S.A.; Chandrika, S.P.; Chandrasekhar, A.; Baby, S.; Subramoniam, A. Antipyretic, analgesic, anti-inflammatory and antioxidant activities of two major chromenes from Melicope lunu-ankenda. J. Ethnopharmacol. 2010, 130, 267-271. [CrossRef] [PubMed] 
9. Barstow, M.; Rehel, S. Melicope lunu-ankenda. Available online: http://www.iucnredlist.org/details /38842/0 (accessed on 16 August 2018).

10. Hartley, T.G. GBIF Secretariat. Melicope lunu-ankenda (Gaertn.). Available online: https://www.gbif.org/ species/3832621 (accessed on 16 July 2018).

11. Shoji, N.; Umeyana, A.; Iuchi, A.; Saito, N.; Arihara, S.; Nomoto, K.; Ohizumi, Y. Two novel alkaloids from Evodia rutaecarpa. J. Nat. Prod. 1989, 52, 1160-1162. [CrossRef]

12. Mawla, F.; Khatoon, S.; Rehana, F.; Jahan, S.; Shelley, M.M.R.; Hossain, S.; Haq, W.M.; Rahman, S.; Debnath, K.; Rahmatullah, M. Ethnomedicinal plants of folk medicinal practitioners in four villages of Natore and Rajshahi districts, Bangladesh. Am. Eur. J. Sustain. Agric. 2012, 6, 406-416.

13. Nguyen, N.H.; Ha, T.K.Q.; Choi, S.; Eum, S.; Lee, C.H.; Bach, T.T.; Chinh, V.T.; Oh, W.K. Chemical constituents from Melicope pteleifolia leaves. Phytochemistry 2016, 130, 291-300. [CrossRef] [PubMed]

14. Sulaiman, M.R.; Mohd Padzil, A.; Shaari, K.; Khalid, S.; Mossadeq, W.M.S.; Mohamad, A.S.; Ahmad, S.; Akira, A.; Israf, D.; Lajis, N. Antinociceptive activity of Melicope ptelefolia ethanolic extract in experimental animals. J. Biomed. Biotechnol. 2011, 2010, 1-6. [CrossRef] [PubMed]

15. Simonsen, H.T.; Adsersen, A.; Bremner, P.; Heinrich, M.; Smitt, U.W.; Jaroszewski, J.W. Antifungal constituents of Melicope borbonica. Phytother. Res. 2004, 18, 542-545. [CrossRef] [PubMed]

16. Rai, P.P.; Matainaho, T.; Saulei, S.; Ambihaipahar, U. Medicinal Plants in Papua New Guinea: Information on 126 Commonly Used Medicinal Plants in Papua New Guinea; Cordell, G.A., Ed.; World Health Organization: Geneva, Switzerland, 2009.

17. Matu, E.N.; Hartley, T.G. Melicope madagascariensis (Baker). In Medicinal Plants/Plantes Médicinales 2; PROTA: Wageningen, The Netherlands, 2011; Volume 11.

18. George, S.; Ajikumaran Nair, S.; Johnson, A.J.; Venkataraman, R.; Baby, S. O-Prenylated flavonoid, an antidiabetes constituent in Melicope lunu-ankenda. J. Ethnopharmacol. 2015, 168, 158-163. [CrossRef] [PubMed]

19. Ramli, I.; Kamarulzaman, N.H.; Shaari, K.; Ee, G.C.L. p-O-Geranylcoumaric acid from Melicope lunu-ankenda. Nat. Prod. Res. 2004, 18, 289-294. [CrossRef] [PubMed]

20. Tan, L.Y.; Yin, W.-F.; Chan, K.-G. Silencing quorum sensing through extracts of Melicope lunu-ankenda. Sensors 2012, 12, 4339-4351. [CrossRef] [PubMed]

21. Al-Zuaidy, M.H.; Mumtaz, M.W.; Hamid, A.A.; Ismail, A.; Mohamed, S.; Abdul Razis, A.F. Biochemical characterization and $1 \mathrm{H}$ NMR based metabolomics revealed Melicope lunu-ankenda leaf extract a potent anti-diabetic agent in rats. BMC Complement. Altern. Med. 2017, 17, 359. [CrossRef] [PubMed]

22. Rao, D.M.; Pullaiah, T. Ethnobotanical studies on some rare and endemic floristic elements of Eastern Ghats-Hill Ranges of South East Asia, India. Ethnobot. Leafl. 2007, 11, 52-70.

23. Al-Zuaidy, M.H.; Hamid, A.A.; Ismail, A.; Mohamed, S.; Abdul Razis, A.F.; Mumtaz, M.W.; Salleh, S.Z. Potent antidiabetic activity and metabolite profiling of Melicope lunu-ankenda leaves. J. Food Sci. 2016, 81, C1080-C1090. [CrossRef] [PubMed]

24. McCormick, J.L.; McKee, T.C.; Cardellina, J.H.; Boyd, M.R. HIV inhibitory natural products. 26. quinoline alkaloids from Euodia roxburghiana. J. Nat. Prod. 1996, 59, 469-471. [CrossRef] [PubMed]

25. Mohan, P.S.; Ramesh, M.; Shanmugam, P. Studies on the Indian Rutaceae. Chemical Investigation of Limonia alata and Evodia lunu-ankenda. J. Nat. Prod. 1985, 48, 501. [CrossRef]

26. Jagadeesh, S.G.; David Krupadanam, G.L.; Srimannarayana, G. Antifeedant activity of the constituents of Evodia lunu-ankenda. Indian J. Chem. 2000, 39B, 475-476.

27. Lal, B.; Bhise, N.B.; Gidwani, R.M.; Lakdawala, A.D.; Joshi, K.; Patvardhan, S. Isolation, synthesis and biological activity of evolitrine and analogs. Arkivoc 2005, 2, 77-97.

28. Sabulal, B.; George, V.; Shiburaj, S. Volatile constituents and antibacterial activity of the flower oil of Evodia lunu-ankenda (Gaertn) Merr. J. Essent. Oil Res. 2006, 18, 462-464. [CrossRef]

29. Manandhar, M.D.; Hussaini, F.A.; Kapil, R.S.; Shoeb, A. Bacteriostatic heterocycles from Euodia lunu-ankenda. Phytochemistry 1985, 24, 199-200. [CrossRef]

30. Kumar, V.; Karunaratne, V.; Sanath, M.R.; Meegalle, K.; MacLeod, J.K. Two fungicidal phenylethanones from Euodia lunu-ankenda root bark. Phytochemistry 1990, 29, 243-245. [CrossRef]

31. Ito, C.; Matsui, T.; Tokuda, H.; Tan, H.T.W.; Itoigawa, M. Cancer chemopreventive constituents from Melicope lunu-ankenda. Phytochem. Lett. 2017, 20, 172-176. [CrossRef]

32. Young, L.S.; Rickinson, A.B. Epstein-Barr virus: 40 years on. Nat. Rev. Cancer 2004, 4, 757-768. [CrossRef] [PubMed] 
33. 4-Methoxy-1-methylquinolin-2-one. 2005. Available online: https://pubchem.ncbi.nlm.nih.gov/compound/ 182073\#section=2D-Structure (accessed on 9 July 2018).

34. Pseudoseletine. 2005. Available online: https://pubchem.ncbi.nlm.nih.gov/compound $/ 621853 \#$ section= 2D-Structure (accessed on 9 July 2018).

35. Kokusaginine. 2005. Available online: https://pubchem.ncbi.nlm.nih.gov/compound/10227\#section=2DStructure (accessed on 9 July 2018).

36. Roxiamine A. 2005. Available online: https:// pubchem.ncbi.nlm.nih.gov/ compound /3000862\#section=2DStructure (accessed on 9 July 2018).

37. Roxiamine B. 2006. Available online: https://pubchem.ncbi.nlm.nih.gov//compound/638622\#section=2DStructure (accessed on 9 July 2018).

38. Roxiamine C. 2005. Available online: https:// pubchem.ncbi.nlm.nih.gov/ compound/3000863\#section=2DStructure (accessed on 9 July 2018).

39. Fagarine. 2005. Available online: https://pubchem.ncbi.nlm.nih.gov/compound/107936\#section=2DStructure (accessed on 9 July 2018).

40. Alloevodionol. 2005. Available online: https://pubchem.ncbi.nlm.nih.gov/compound/alloevodionol (accessed on 9 July 2018).

41. Isoevodionol. 2006. Available online: https://pubchem.ncbi.nlm.nih.gov/compound $/ 11128652 \#$ section= Top (accessed on 9 July 2018).

42. 7-[(E)-4-Hydroxy-3-methylbut-2-enoxy]chromen-2-one. 2006. Available online: https://pubchem.ncbi.nlm. nih.gov/compound/11644447\#section=2D-Structure (accessed on 9 July 2018).

43. Marmesin. 2005. Available online: https://pubchem.ncbi.nlm.nih.gov/compound/604512\#section=2DStructure (accessed on 9 July 2018).

44. Umbelliferone. 2004. Available online: https://pubchem.ncbi.nlm.nih.gov/compound/7hydroxycoumarin\#section=2D-Structure (accessed on 9 July 2018).

45. Bergapten. 2004. Available online: https://pubchem.ncbi.nlm.nih.gov/compound/2355\#section=2DStructure (accessed on 9 July 2018).

46. beta-Ocimene. 2005. Available online: https://pubchem.ncbi.nlm.nih.gov $/$ compound $/ 5281553 \#$ section= 2D-Structure (accessed on 9 July 2018).

47. Lupeol. 2005. Available online: https://pubchem.ncbi.nlm.nih.gov/compound /259846\#section=2DStructure (accessed on 9 July 2018).

48. Lalitha, K.G.; Venkatachalam, T.; Rathinavel, G.; Kumar, V.K.; Kalaiselvi, P. Evaluation of analgesic activity of Evodia lunu-ankenda (Gaertn) Merr. bark. Der Pharm. Sin. 2010, 1, 7-10.

49. Venkatachalam, T.; Rathinavel, G.; Kumar, V.K.; Kalaiselvi, P.; Lalitha, K.G.; Senthilkumar, K.L. In vitro comparative anthelmintic activity of Evodia lunu-ankenda (Gaertn) Merr. bark and Abutilon indicum (Linn.) sweet leaves. Der Pharm. Chem. 2010, 2, 164-169.

50. Al-Zuaidy, M.H.; Ismail, A.; Mohamed, S.; Abdul Razis, A.F.; Mumtaz, M.W.; Abdul Hamid, A. Antioxidant effect, glucose uptake activity in cell lines and cytotoxic potential of Melicope lunu-ankenda leaf extract. J. Herb. Med. 2018, in press. [CrossRef]

51. Kim, J.H.; Kim, J.-K.; Ahn, E.-K.; Ko, H.-J.; Cho, Y.-R.; Lee, C.H.; Kim, Y.K.; Bae, G.-U.; Oh, J.S.; Seo, D.-W. Marmesin is a novel angiogenesis inhibitor: Regulatory effect and molecular mechanism on endothelial cell fate and angiogenesis. Cancer Lett. 2015, 369, 323-330. [CrossRef] [PubMed]

52. Kim, J.H.; Kim, M.S.; Lee, B.H.; Kim, J.-K.; Ahn, E.-K.; Ko, H.-J.; Cho, Y.-R.; Lee, S.-J.; Bae, G.-U.; Kim, Y.K.; et al. Marmesin-mediated suppression of VEGF/VEGFR and integrin $\beta 1$ expression: Its implication in non-small cell lung cancer cell responses and tumor angiogenesis. Oncol. Rep. 2017, 37, 91-97. [CrossRef] [PubMed]

53. Yang, J.H.; Shin, B.Y.; Han, J.Y.; Kim, M.G.; Wi, J.E.; Kim, Y.W.; Cho, I.J.; Kim, S.C.; Shin, S.M.; Ki, S.H. Isorhamnetin protects against oxidative stress by activating $\mathrm{Nrf} 2$ and inducing the expression of its target genes. Toxicol. Appl. Pharmacol. 2014, 274, 293-301. [CrossRef] [PubMed]

54. Yokozawa, T.; Kim, H.Y.; Cho, E.J.; Choi, J.S.; Chung, H.Y. Antioxidant effects of isorhamnetin 3,7-Di-O- $\beta$-d-glucopyranoside isolated from Mustard Leaf (Brassica juncea) in rats with streptozotocin-induced diabetes. J. Agric. Food Chem. 2002, 50, 5490-5495. [CrossRef] [PubMed]

55. Verma, A.; Dewangan, P.; Kesharwani, D.; Kela, S.P. Hypoglycemic and hypolipidemic activity of scopoletin (coumarin derivative) in streptozotocin induced diabetic rats. Int. J. Pharm. Sci. Rev. Res. 2013, 22, 79-83. 
56. Panda, S.; Kar, A. Evaluation of the antithyroid, antioxidative and antihyperglycemic activity of scopoletin from Aegle marmelos leaves in hyperthyroid rats. Phytother. Res. 2006, 20, 1103-1105. [CrossRef] [PubMed]

57. Izzreen, I.; Noriham, A. Evaluation of the antioxidant potential of some Malaysian herbal aqueous extracts as compared with synthetic antioxidants and ascorbic acid in cakes. Int. Food Res. J. 2011, 18, 583-587.

58. Lou, Z.; Wang, H.; Rao, S.; Sun, J.; Ma, C.; Li, J. p-Coumaric acid kills bacteria through dual damage mechanisms. Food Control 2012, 25, 550-554. [CrossRef]

(c) 2018 by the authors. Licensee MDPI, Basel, Switzerland. This article is an open access article distributed under the terms and conditions of the Creative Commons Attribution (CC BY) license (http://creativecommons.org/licenses/by/4.0/). 